\title{
Economic, Socio-Cultural, and Environmental Impacts on Community Support for Tourism: A Case in Harapan Island, Kepulauan Seribu
}

\author{
Levyda* \\ Management Department, Sahid University \\ Jl. Prof. DR. Soepomo No.84, Jakarta Selatan 12870, Indonesia \\ levyda_mm@yahoo.co.id
}

Received: $25^{\text {th }}$ March 2020/ Revised: $8^{\text {th }}$ May 2020/ Accepted: $21^{\text {st }}$ July 2020

How to Cite: Levyda. (2020). Economic, Socio-Cultural, and Environmental Impacts on Community Support for Tourism: A Case in Harapan Island, Kepulauan Seribu. Binus Business Review, 11(3), 217-227. https://doi.org/10.21512/bbr. v11i3.6348

\begin{abstract}
The research aimed to examine economic, socio-cultural, and environmental impacts on community support for tourism in Harapan Island, Kepulauan Seribu. Data were collected using a questionnaire. The population was the people of Harapan Island. Around 100 residents were selected as respondents through accidental sampling. Then, data were processed using Partial Least Squares Structural Equation Modeling (PLS-SEM) version 3.2.8. Based on the hypothesis test, economic and socio-cultural factors significantly influence community support. Sociocultural factors have the most significant effect on community support. Meanwhile, environmental factors do not affect community support. The research contributes to the model of community support for the development of tourism on a small island. To increase community support, it is necessary to increase the income of the community, job opportunities, security, protection of traditional culture, and welfare.
\end{abstract}

Keywords: economic impact, socio-cultural impact, environmental impact, community support, tourism

\section{INTRODUCTION}

Before the COVID-19 pandemic, the tourism sector created significant employment worldwide and contributed a significant share of gross domestic product (Cárdenas-García \& Pulido-Fernández, 2019). It also happens in Indonesia (Kementerian Pariwisata dan Ekonomi Kreatif RI, 2019; Adhikrisna, Hidayat, \& Arifin, 2016). The community enjoys tourism's contribution to job creation and income (Amalia, Kusumawati, \& Hakim, 2018; Pratiwi \& Pinasti, 2017).

Kepulauan Seribu is a national priority destination located in Jakarta Bay. It consists of 110 islands and has north and south sub-districts. The north sub-district includes 76 islands divided into three villages: Harapan Village, Kelapa Village, and Panggang Village. Meanwhile, the south sub-district consists of 31 islands divided into three villages, namely Tidung Village, Pari Village, and Jawa Village
(Badan Pusat Statistik Kabupaten Kepulauan Seribu, 2019). In here, there are some snorkeling spots and a national marine park. The park is a nature reserve. It is divided into several zones: turtle protection zones, coral reef ecosystems, and mangrove forests. There is a zone for tourism outside of these zones consisting of 49 islands and residential zones (Afifah, Sabila, \& Hardi, 2019).

As a national priority destination, Kepulauan Seribu is expected to receive visits from foreign and domestic tourists. To achieve the target of tourist visits, the government has applied various strategies. Indonesia's tourism development in 2015-2019 includeddeveloping tourismdestinations, strengthening marketing, strengthening industrial competitiveness, strengthening institutions, and improving the quality of human resources (Kementerian Pariwisata dan Ekonomi Kreatif RI, 2019).

Even though the development to support tourism in Harapan Island has been carried out, the community 
support is still not optimal. Tourist spending is more enjoyed by travel agents than the residents (Goni \& Yustika, 2019). Residents manage many homestays, but they do not have financial literacy (Paranita, Levyda, \& Giyatmi, 2019). Many residents who are guides are not aware of the importance of maintaining coral reefs and marine life. Similarly, public awareness to manage waste is still low, so it is not convenient for tourists. Hence, community support determines sustainable tourism development. The research will examine whether economic, socio-cultural, and environmental factors can increase community support for tourism. The results of this study can be used as a guide for tourism development supported by the community.

Sustainable tourism emphasizes the balance of environmental, economic, and socio-cultural aspects in the long run (Lee, Zhang, \& Ng, 2019). The benefits of sustainable tourism development must be distributed equitably to all stakeholders, especially the community. Therefore, the economic, socio-cultural, and environmental impacts on community support for tourism are significant.

At present, the measurement of community support for marine tourism is still limited. The research develops measurements by referring to the definition and measurements from previous studies and the characteristics of Harapan Island. Some previous researchers have discussed community support for tourism intensively. The studies vary according to location and type of tourism. Li and Wan (2017) investigated community support for the tourism festival. Then, Yu, Cole, and Chancellor (2018) and Lim, Lo, Mohamad, Chin, and Ramayah (2017) studied community support for rural tourism.

Meanwhile, Boonsiritomachai and Phonthanukitithaworn (2019), Bakhsh, Potwarka, Nunkoo, and Sunnassee (2018), and Séraphin, Platania, Spencer, and Modica (2018) studied sports events. Rasoolimanesh, Jaafar, Kock, and Ahmad (2017) analyzed community support for heritage tourism. Naidoo and Sharpley (2016) focused on agro-tourism research. Chang and Huang (2017) and Liao, Yang, and Chang (2015) conducted studies on marine tourism on a small island. They concluded that tourism provided benefits to the population despite the different benefits perceived by the community. Residents were positive if the benefits expected from tourism were more significant than the costs they have to bear. Alonso and Nyanjom (2016) and $\mathrm{Su}$ and Swanson (2020) also strengthened the idea by saying that community support for tourism was based on the benefits that the residents received. Then, García, Vázquez, and Macías (2015) mentioned that community support for tourism had a positive or negative impact on supporting tourism development, promoting the island, and taking advantage of tourism opportunities.

Several theories are often used to describe the community support for tourism, such as growth machines, community attachment, social exchange, rationality, and empowerment from Weber (Gursoy,
Ouyang, Nunkoo, \& Wei, 2019). The Social Exchange Theory (SET) contributes to the research of local support for tourism (Nunkoo \& So, 2016). Previous researchers use SET to explain how residents sharpen their perception of tourism (Martín, Martínez, \& Fernández, 2018). It is used to see the interaction of individuals and groups in the exchange of activities and resources. Many researchers use SET because people's perception of tourism can explain community support for tourism. SET is proven to be credible in explaining community support for tourism development through meta-analysis (Gursoy et al., 2019).

Until now, there has been no agreement on measuring the impact of tourism. There are two measurement models: multidimensional measurement (the positive impact is separated from the negative impact) and unidimensional measurement. A multidimensional analysis refers to the SET that tourism has a psychological and negative impact (Šegota, Mihalič, \& Kuščer, 2017). On the contrary, unidimensional measurement is based on the assumption that residents perceive tourism as having a positive impact and not worrying about negative effects (García et al., 2015). Under assumption that tourism has a positive impact, the research uses unidimensional measurements

The analysis of the impact on tourism is required to receive great support from the community. The effect of tourism has not been generalized. Empirical research on tourism indicates different economic, socio-cultural, and environmental impacts felt by the people in the islands.

The positive impact on the economy influences community support for tourism on the island (Hsu, Chen, \& Yang, 2019; Hussain, Ali, Nair, Ragavan, \& Nair, 2019; Eshliki \& Kaboudi, 2017; Chang \& Huang, 2017). The positive or negative economic impacts are in the form of an increasing in incomes (Boonsiritomachai \& Phonthanukitithaworn, 2019; Martín et al., 2018; García et al., 2015), employment opportunities (Boonsiritomachai \& Phonthanukitithaworn, 2019), welfare (García et al., 2015), price in general (Martín et al., 2018; García et al., 2015), and land price (Martín et al., 2018; García et al., 2015) due to increasing demands.

The positive impact of social culture on community support for tourism in the islands is also confirmed (Hussain et al., 2019; Eshliki \& Kaboudi, 2017). On the contrary, it is found that most of Solomon Island residents assess that tourism has a negative impact on social culture because of the limitations of social capital and foreign influence. However, it has a positive impact on the economy (Diedrich \& Aswani, 2016). The perceived impacts on tourism depend on the role of residents in tourism (Nejati, Mohamed, \& Omar, 2014). The social culture of tourism is the positive or negative impact in the form of improvement of infrastructure (García et al., 2015), ease of transportation (García et al., 2015), the pride of the area (Boonsiritomachai \& Phonthanukitithaworn, 2019; García et al., 2015), good relationships (García et 
al., 2015), drug and alcohol abuse (Martín et al., 2018; García et al., 2015); and maintained traditions and culture (García et al., 2015). In the multidimensional model, positive and negative socio-culture effects in tourism support are found (Yu et al., 2018).

Moreover, the positive impact of the environment affects community support for tourism (Hussain et al., 2019). However, some previous researchers agree that the environmental factor does not affect community support for tourism (Hsu et al., 2019; Eshliki \& Kaboudi, 2017). The positive or negative environmental impacts are in the form of a more beautiful island, greener island, and cleaner sea (García et al., 2015). It is concluded that positive environmental impacts do not affect tourism support while negative effects affect it (Yu et al., 2018).

The economy has the highest effect on community support. Meanwhile, the second highest is social-culture, and the lowest is the environment (Hussain et al., 2019; Eshliki \& Kaboudi, 2017). A positive economy influences tourism support, while a negative economy does not affect tourism support (Yu et al., 2018). There is a conclusion that the greater the positive economic impact is, the greater the support for tourism will be. Moreover, the environmental impacts on tourism support are indirect through economic impacts (Hsu et al., 2019).

Each local population has different characteristics, so that the results of the previous research cannot be generalized. There are differences in the empirical results of economic, socio-cultural, and environmental impacts on community support. Therefore, it is necessary to study community support for tourism in Harapan Island. It needs to be re-tested to increase the effects of tourism on Harapan Island.

Based on the previous study discussed, economic, socio-cultural, and environmental factors are predicted to influence the community support of tourism development in Harapan Island. In the preliminary research, residents of Harapan Island tend to give positive responses, so the researcher concentrates on the positive impact of tourism. Hence, the research hypotheses are as follows.

$\mathrm{H}_{1}$ : The economic impact influences community support for tourism development.

$\mathrm{H}_{2}$ : The socio-cultural impact influences community support for tourism development.

$\mathrm{H}_{3}$ : The environmental impact influences community support for tourism development.

\section{METHODS}

The used method is quantitative research. The population of the research is the people of Harapan Island. The number of respondents is 100 people with accidental sampling. Data are collected using a hard copy questionnaire. The survey was conducted from June to December 2019.

The measurement of perceived economic impact, socio-cultural impact, environmental impact, and community support is developed based on the theory discussed and the conditions of the research object. The variables are interval scales measured by a five-point Likert scale. The categories of the Likert scale are strongly disagree (1), disagree (2), neither disagree nor agree (3), agree (4), and strongly agree (5). The variables are described by their means.

Similarly, structural models and hypotheses are developed based on the theory discussed. Because the number of samples of the research is only 100, the researcher uses Partial Least Squares Structural Equation Modeling (PLS-SEM) with Smart PLS 3.2.8 to test the model and the hypotheses. Data processing procedures with PLS comprises constructing structural models (inner models) and measurement models (outer models), collecting data, evaluating measurement models and structural models, testing hypotheses, and interpreting results (Hair Jr. et al., 2017). Before testing hypotheses, structural models (inner models) and measurement models (outer models) based on theory must be evaluated first.

The assessments aim to obtain accurate measurements. The reliability and validity assessments must be carried out on the research constructs and the indicators. The research uses internal consistency and reliability indicators to test reliability. The test equipment used is composite reliability and Cronbach's alpha. Moreover, the researcher utilizes convergent validity and discriminant validity to test validity. Convergent validity uses loading factor, reliability indicator, and Average Variance Extract (AVE). Meanwhile, for discriminant validity, the test tool is cross-loadings and Fornell-Larcker criterion. Then, the structural model is evaluated by the coefficient of determinant, predictive relevance, size, significance of the path coefficients, and effect sizes $\left(\mathrm{f}^{2}\right)$ (Hair Jr. et al., 2017). Last, the hypothesis is tested using the student's t-test.

\section{RESULTS AND DISCUSSIONS}

The characteristics of respondents are listed in Table 1. Most of the respondents are women $(73 \%)$ and married $(76 \%)$. For age, the respondents are mainly between 31 to 40 years (43\%). Moreover, most of them graduate from high school $(47 \%)$. For occupation, most of them are private employees (33\%).

The residents in Harapan Island perceive the high economic impact of tourism in the form of increased income and employment. The community's perception, in line with economic growth, is measured by household consumption expenditure. From 2015 to 2018 , the economy grew because of increased purchasing power. The economic growth in Kepulauan Seribu in 2015 was $4,45 \%$. In 2016 , it rose to $4,94 \%$. In 2017 and 2018, it was 5,43\% and 5,53\%, respectively. The expenditure in 2018 was $28,25 \%$ for food, and the remaining $(71,75 \%)$ was for non-food (Badan Pusat Statistik Kabupaten Kepulauan Seribu, 2020). The 
region is quite prosperous, as seen from the sizable non-food spending.

The number of tourists visiting Harapan Island in 2018 was 84.486, and in 2017, it was 95.179 (Badan Pusat Statistik Kabupaten Kepulauan Seribu 2019, 2018). The community responds to tourism development by offering boat rental services, homestays, and food and beverage services, and producing and selling souvenirs and tour guides. Those efforts result in the increase in sales. There are 35 homestays, 4 restaurants, 130 boats, and 11 motorboats. Therefore, the community assesses an increase in income, employment opportunities, and welfare due to tourism.

Moreover, tourism has an impact on increasing the price of goods and land. The price of products in Harapan Island is higher than in Jakarta because of the high distribution costs and the absence of traditional markets (Badan Pusat Statistik Kabupaten Kepulauan Seribu, 2019). Tourism will affect the price of goods, especially consumer goods. Similarly, the land in Pulau Harapan is limited, but the population continues to increase. It affects the land price. As the residents use their property to build homestays, it also affects the land price.

Tourism facilities consist of community and non-community buildings, infrastructure (roads, bridges, and docks), other buildings, machines and equipment, transportation, and other capital goods. The development of facilities and infrastructure has been intensively carried out since the enactment of Kepulauan Seribu as a national tourism strategic area in 2015 (Badan Pusat Statistik Kabupaten Kepulauan Seribu, 2019). Therefore, residents perceive tourism as a positive impact on the development of facilities, infrastructure, and transportation. The positive impact of tourism in the form of infrastructure supports the conclusion of (Chang \& Huang, 2017). Because tourists often visit the area, the community becomes proud of it. The effect of tourism on the pride of residents is relatively high.

As a tourist destination, more parties, such as education and business institutions, participate in environmental preservation and cleanliness (Badan Pusat Statistik Kabupaten Kepulauan Seribu, 2019) and community empowerment for ecological conservation. Therefore, residents consider that tourism has a significant impact on the environment. The effect of tourism on the greening and density of Harapan Island is highly ranked. Garbage is one of the problems in Harapan Island, although various methods of waste management have been implemented by the local government, the community, and other parties. Hence, community support for tourism development as measured by population support, tourism promotion, and business is classified high.

Next, to examine the economic, socio-cultural, and environmental effects on community support, SEM with the PLS approach 3.2.8 is used. The proposed model is illustrated in Figure 1.

Table 1 Characteristics of Respondents

\begin{tabular}{|c|c|c|c|}
\hline Characteristics & Options & $\begin{array}{l}\text { Number of } \\
\text { respondents }\end{array}$ & Percentage $(\%)$ \\
\hline \multirow[t]{2}{*}{ Gender } & Male & 27 & 27 \\
\hline & Female & 73 & 73 \\
\hline \multirow[t]{3}{*}{ Marital status } & Married & 76 & 76 \\
\hline & Single & 23 & 23 \\
\hline & Widower/widow & 1 & 1 \\
\hline \multirow[t]{5}{*}{ Age } & $>20$ years old & 5 & 5 \\
\hline & 20-30 years & 20 & 20 \\
\hline & $31-40$ years old & 43 & 43 \\
\hline & $41-50$ years & 25 & 25 \\
\hline & $51-60$ years old & 7 & 7 \\
\hline \multirow[t]{5}{*}{ Education } & Elementary school & 10 & 10 \\
\hline & Middle School & 14 & 14 \\
\hline & High school & 47 & 47 \\
\hline & Diploma (D1 / D2 / D3) & 10 & 10 \\
\hline & D4 / S1 & 19 & 19 \\
\hline \multirow[t]{5}{*}{ Occupation } & Private employee & 33 & 33 \\
\hline & Civil servant & 13 & 13 \\
\hline & Entrepreneur & 29 & 29 \\
\hline & Do not work & 22 & 22 \\
\hline & Others & 3 & 3 \\
\hline
\end{tabular}


Before the measurement and structural tests are carried out, the model must be tested whether it is free from multicollinearity. The multicollinearity test aims to test whether the regression model finds a correlation between independent variables. A good model should not find a correlation between independent variables. To detect the presence or absence of multicollinearity in the model, the researcher uses Variance Inflation Factor (VIF). The cutoff value used to indicate multicollinearity is $\geq 10$ and the value of the correlation between variables. The VIF value is 1,591 for economic impact, 2,211 for socio-cultural impact, and 2,462 for environmental impact. The results of VIF in the indicators are described in Table 2. In the structural model, the VIF values are less than 10. It means that there is no multicollinearity. Because there is no multicollinearity, the built model is good.

Before testing the hypothesis, a measurement assessment (outer model) and a structural assessment (inner model) must be carried out. Measurement assessment focuses on evaluating reliability and validity. Reliability assessment is tested by testing the internal consistency and reliability indicator. Internal consistency is measured by composite reliability. The validity assessment uses convergent validity (Average Variance Extracted (AVE)) and discriminant validity.
Table 2 shows a summary of the measurement model test. The increased income, employment, and welfare are valid as the measurement of economic impact. Therefore, only these three indicators are used in the next process. These indicators have a loading factor between $0,7-0,8$. The t-value obtained for each loading factor indicator of economic impact is greater than 1,96 . These indicators are meaningful to measure economic impact.

Moreover, improved facilities, increased security, and enhanced community relations and cultural preservation are valid indicators of sociocultural impact. The loading factor value of these indicators is between 0,5 and 0,8 . The t-test value is also more than 1,96 . Thus, these indicators can measure the socio-cultural impact.

The increased environmental cleanliness, greening, and sea cleanliness are valid indicators as indicated by the loading factor value for environmental impact. The t-test results also show that the indicators are valid. The indicators can be used to measure environmental impact.

Meanwhile, supporting tourism development, participating in promoting tourism, and doing business in the tourism sector are valid as a measurement of community support. The validity is indicated by the loading factor value and the t-test for each indicator.

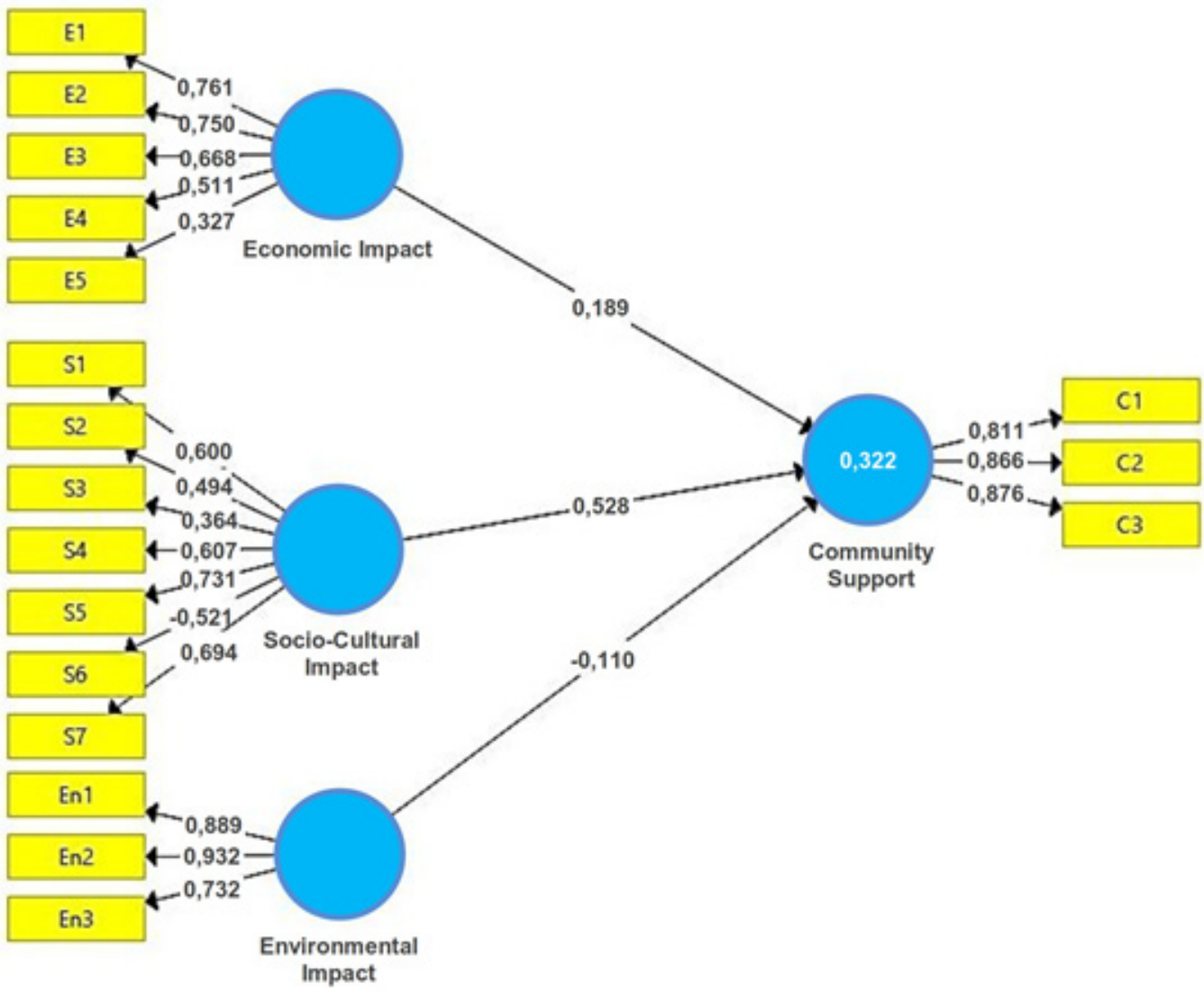

Figure 1 The Proposed Model 
Construct validity is measured by AVE. Meanwhile, the construct reliability is measured by Cronbach's alpha and composite reliability. All variables have satisfactory reliability since the values of Cronbach's alpha are between 0,7 and 0,9. Similarly, the values of composite reliability are more than 0,708 . All variables have acceptable reliability (Hair Jr, Hult, Ringle, \& Sarstedt, 2017). The values of reliability and validity are shown in Table 3 .

Cross loading indicators of the community support are $0,862,0,842$, and 0,838 . These values are greater than all the loadings of the other constructs. It means that community support is different from other constructs (Hair Jr et al., 2017). Cross loading indicators of other constructs also show that they are different from others (see Table 4).

Table 2 The Summary of Measurement Model Test

\begin{tabular}{|c|c|c|c|c|c|c|c|}
\hline Variable & Indicator & $\begin{array}{c}\text { Loading } \\
\text { Factor }(\lambda)\end{array}$ & $\begin{array}{c}\text { Indicator } \\
\text { Reliability }\left(\lambda^{2}\right)\end{array}$ & Error & T-Value & P-Value & Conclusion \\
\hline \multirow{3}{*}{ Economic impact (E) } & E1_income & 0,876 & 0,767 & 0,233 & 17,137 & 0,000 & Valid \\
\hline & E2_employment & 0,766 & 0,586 & 0,414 & 9,201 & 0,000 & Valid \\
\hline & E3_welfare & 0,763 & 0,582 & 0,418 & 12,075 & 0,000 & Valid \\
\hline \multirow{4}{*}{ Socia-cultural impact (S) } & $\mathrm{S} 1$ fasilities & 0,599 & 0,359 & 0,641 & 7,041 & 0,000 & Valid \\
\hline & S4_relationship & 0,706 & 0,498 & 0,502 & 8,992 & 0,000 & Valid \\
\hline & S5_security & 0,835 & 0,697 & 0,303 & 12,382 & 0,000 & Valid \\
\hline & S7_tradition & 0,751 & 0,564 & 0,436 & 8,623 & 0,000 & Valid \\
\hline \multirow{3}{*}{$\begin{array}{l}\text { Environmental impact } \\
\text { (En) }\end{array}$} & En1_cleanliness & 0,890 & 0,792 & 0,208 & 26,833 & 0,000 & Valid \\
\hline & En2_greening & 0,931 & 0,866 & 0,134 & 55,511 & 0,000 & Valid \\
\hline & En3_sea & 0,733 & 0,537 & 0,463 & 7,342 & 0,000 & Valid \\
\hline \multirow{3}{*}{ Community support (C) } & C1_development & 0,862 & 0,742 & 0,258 & 20,696 & 0,000 & Valid \\
\hline & C2_promote & 0,842 & 0,709 & 0,291 & 10,776 & 0,000 & Valid \\
\hline & C3_business & 0,838 & 0,702 & 0,298 & 14,956 & 0,000 & Valid \\
\hline
\end{tabular}

Table 3 The Summary of Reliability and Validity of the Constructs

\begin{tabular}{lccc}
\hline Variable & AVE & Cronbach's Alpha & Composite Reliability \\
\hline Economic impact & 0,645 & 0,723 & 0,845 \\
Socio-cultural impact & 0,529 & 0,703 & 0,816 \\
Environmental impact & 0,732 & 0,823 & 0,890 \\
Community support & 0,718 & 0,810 & 0,884 \\
\hline
\end{tabular}

Table 4 The Summary of Cross Loading Test

\begin{tabular}{lccccc}
\hline Variable & Indicator & $\begin{array}{c}\text { Community } \\
\text { support }\end{array}$ & $\begin{array}{c}\text { Economic } \\
\text { impact }\end{array}$ & $\begin{array}{c}\text { Environmental } \\
\text { impact }\end{array}$ & $\begin{array}{c}\text { Socio-cultural } \\
\text { impact }\end{array}$ \\
\hline Community support & C1 & 0,862 & 0,433 & 0,441 & 0,423 \\
& C2 & 0,842 & 0,238 & 0,278 & 0,275 \\
Economic impact & C3 & 0,838 & 0,233 & 0,267 & 0,373 \\
& E1 & 0,338 & 0,876 & 0,513 & 0,375 \\
Environmental impact & E2 & 0,265 & 0,766 & 0,391 & 0,406 \\
& E3 & 0,299 & 0,763 & 0,508 & 0,417 \\
En1 & 0,414 & 0,556 & 0,890 & 0,696 \\
& En2 & 0,374 & 0,531 & 0,931 & 0,652 \\
& En3 & 0,194 & 0,400 & 0,733 & 0,404 \\
& S1 & 0,272 & 0,240 & 0,434 & 0,599 \\
& S4 & 0,247 & 0,478 & 0,505 & 0,706 \\
& S5 & 0,423 & 0,317 & 0,498 & 0,835 \\
\hline
\end{tabular}


The results of the discriminant validity test with the Fornell-Larcker criterion are in Table 5. The AVE root value for each variable is greater than the correlation value between one construct and another. These results indicate that each construct in the research is different from other constructs (Hair Jr et al., 2017).

The structural model (inner model) is assessed using $\mathrm{R}$-squared $\left(\mathrm{R}^{2}\right)$. The value of $\mathrm{R}^{2}$ indicates the prediction accuracy of the model (Hair Jr et al., 2017). The $\mathrm{R}^{2}$ value shows weak effect $(0,25)$, moderate effect $(0,5)$, and substantial effect $(0,75)$ (Chin, 2010). The $\mathrm{R}^{2}$ value for the final model is 0,229 . It is included in the weak category. The result indicates that $22,9 \%$ of community support are influenced by economic, socio-cultural, and environmental impacts. The final proposed model is described in Figure 2.

Hypotheses are tested by t-statistical test. The limit of rejecting and accepting the hypotheses is in the range of values $-1,96$ to 1,96 . Based on Table 6 , the relationship of economic impact and community support is shown by the path coefficient of 0,189 with $t$-value of 2,119 and $p$-value of 0,037 . It means that the economy affects community support. $\mathrm{H}_{1}$ is accepted. The direct effect of the economic impact on community support is $3,6 \%((0,189 \times 0,189) \times 100 \%)$. It means that economic impact has $3,6 \%$ influence on community support. Moreover, the effect value $\left(\mathrm{f}^{2}\right)$ of economic impact is 0,033 , indicating a small effect.

Table 5 The Summary of Fornell-Larcker Criterion Test

\begin{tabular}{lcccc}
\hline & $\begin{array}{c}\text { Community } \\
\text { support }\end{array}$ & $\begin{array}{c}\text { Economic } \\
\text { impact }\end{array}$ & $\begin{array}{c}\text { Environmental } \\
\text { impact }\end{array}$ & $\begin{array}{c}\text { Socio-cultural } \\
\text { impact }\end{array}$ \\
\hline Community support & 0,847 & & & \\
Economic impact & 0,377 & 0,803 & & \\
Environmental impact & 0,406 & 0,590 & 0,855 & \\
Socio-cultural impact & 0,434 & 0,494 & 0,711 & 0,728 \\
\hline
\end{tabular}

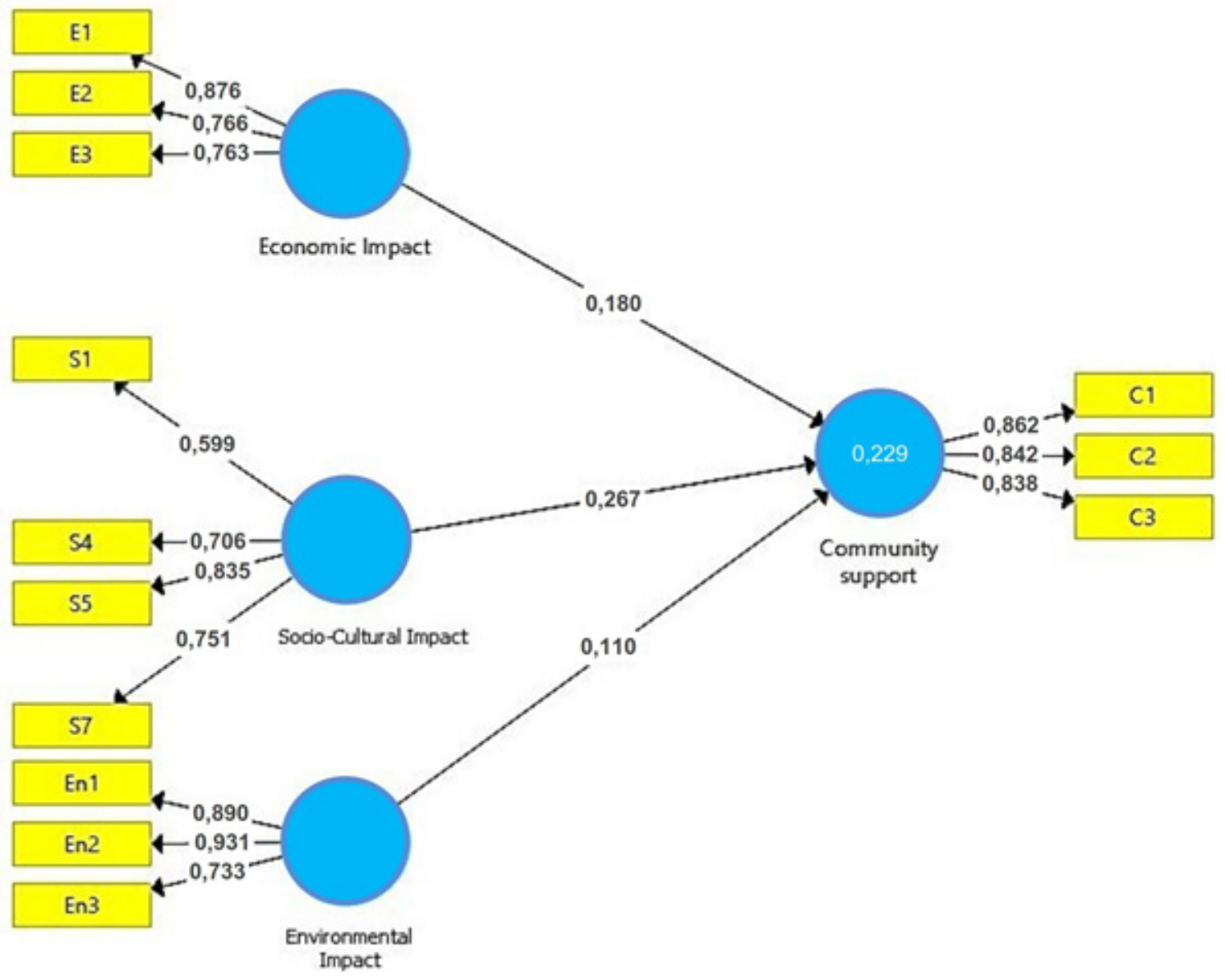

Figure 2 The Final Proposed Model 
The economic factor affects community support for the tourism development of Harapan Island. The result supports Hsu et al. (2019), who stated that the greater the economic benefits were, the greater the community's support for tourism would be. The result is also in line with Hussain et al. (2019) and Eshliki and Kaboudi (2017). To increase community support, it should focus on growing income, employment, and community welfare. There are two elements of increasing income: increasing the number of tourists and ensuring tourists to spend more. To increase the number of tourists, it is necessary to increase the number of tourist attractions, the promotion of tourist attractions, and supporting facilities, especially transportation from Jakarta to Harapan Island. Tourists' expenses received by residents are expenses for homestays, food and drinks, boat rental, and guide services. Currently, the expenditure of tourists received by residents is still limited because tourists buy tour packages from travel agents. The marketing capabilities of the residents need to be improved so they can offer the services directly.

Next, the path coefficient indicates that the sociocultural impact on community support is 0,528 with $\mathrm{t}$-value of 4,089 and $\mathrm{p}$-value of 0,000 . The t-statistic value is more significant than t-critical $(1,960)$, and the $\mathrm{p}$-value is smaller than 0,05 . It means that social culture influences community support. $\mathrm{H}_{2}$ is accepted. The direct influence of socio-cultural impact on community support is $27,9 \%((0,528 \times 0,528) \times 100 \%)$. It implies that the socio-cultural impact has $27.9 \%$ influence on community support. The effect size ( $\left.\mathrm{f}^{2}\right)$ of socio-cultural impact is 0,186 , which is in the medium category.

The socio-cultural factors influence community support for the tourism development of Harapan Island. The result supports Yu et al. (2018). They agreed that the negative and positive socio-cultural impacts affected the support of tourism. It is also in line with Hussain et al. (2019) and Eshliki and Kaboudi (2017). The arrival of tourists can disturb the security of residents. Community support for tourism development will be high as long as it does not interfere with the community's security. Beach and marine tourism in Harapan Island are mass tourism that is relatively cheap. Some security disturbances felt by residents are loss and damage to homestay assets. Homestay owners find it challenging to regulate the use of homestays because they do not deal directly with guests. Guests buy tour packages, including homestays directly from the travel agency. It is necessary to have a mutually beneficial business relationship between travel agents and homestay owners. However, residents support tourism because it does not interfere with their traditions and habits. Most residents are fishermen and Muslim who came from various tribes. Therefore, tourism development must pay attention to these aspects. Socio-cultural associations such as youth clubs, women's clubs, and sports clubs must be involved in a discussion.

Next, the t-statistic of environmental impact on community support is smaller than t-critical $(1,960)$ with the p-value of 0,05 . The result means that the environmental impact does not significantly influence community support. $\mathrm{H}_{3}$ is rejected. The effect size $\left(\mathrm{f}^{2}\right)$ of the environmental impact is 0,007 . This $\mathrm{f}^{2}$ shows the contribution of the construct to the dependent variable. Thus, the effect of the environment on community support is small.

Significantly, the environmental factor does not affect community support for tourism. The result is different from Hussain et al. (2019). They concluded that the environment affected community support. It may be due to the limited number of measurements in this model (Yu et al., 2018). Environmental impact can be both positive and negative. The research focuses on the positive environmental impact, as the population feels positive it on tourism. Many tourists accidentally damage the environment, such as stepping on a coral reef while snorkeling (Rosalina, Yonvitner, \& Imran, 2019). It seems that many residents do not realize that it will have an adverse impact in the future, especially residents who work as snorkeling guides. They often pay more attention to the positive impact of income. The environmental impact is likely indirect on community support for tourism so that the

Table 6 The Hypothesis Results

\begin{tabular}{|c|c|c|c|c|c|c|}
\hline Hypothesis & $\begin{array}{c}\text { Original } \\
\text { Sample } \\
(0)\end{array}$ & $\begin{array}{c}\text { Sample } \\
\text { Mean } \\
(\mathrm{M})\end{array}$ & $\begin{array}{l}\text { Standard } \\
\text { Deviation } \\
\text { (STDEV) }\end{array}$ & $\begin{array}{l}\text { T-Statistics } \\
(\mid \text { O/STDEV } \mid)\end{array}$ & P-Values & Conclusion \\
\hline $\begin{array}{l}\text { Economic impact } \rightarrow \\
\text { community support }\end{array}$ & 0,189 & 0,242 & 0,089 & 2,119 & 0,037 & Significant \\
\hline $\begin{array}{l}\text { Socio-cultural impact } \rightarrow \\
\text { community support }\end{array}$ & 0,528 & 0,523 & 0,129 & 4,089 & 0,000 & Significant \\
\hline $\begin{array}{l}\text { Environmental impact } \rightarrow \\
\text { community support }\end{array}$ & $-0,110$ & $-0,121$ & 0,144 & 0,760 & 0,449 & Insignificant \\
\hline
\end{tabular}


direct impact does not affect the local community's support for tourism. The environmental impacts on community support are indirect through economic impacts. It is positively correlated with socio-cultural impact and negatively correlated with economic impact. Therefore, increasing some aspects of sociocultural impact will improve the environment, such as the habit of cleaning up the environment.

\section{CONCLUSIONS}

Based on the result, all impacts are perceived positively. The residents of Harapan Island feel quite high economic impacts, such as increasing incomes, employment opportunities, and welfare. Those indicators are valid and reliable. Similarly, they also notice high socio-cultural impacts. The indicators are people's pride, good relations among the population, transportation, infrastructure and facilities, maintained traditions and culture, and better security. However, only indicators of good relations, maintained traditions and culture, and better security are valid and reliable. Moreover, the environmental impacts are also perceived as high. A cleaner and greener environment and a more maintained sea are valid and reliable indicators. Community support is very high. Support for development, participation in promoting tourism, and taking advantage of tourism opportunities are valid and reliable indicators.

The structural model of the relationship of economic, socio-cultural, and environmental factors on community support for tourism is good. However, the economic and environmental factors on community support are small. Meanwhile, the effect size of sociocultural impacts on community support is moderate. The R-squared model of community support caused by economic, socio-cultural, and environmental factors is relatively weak. Then, the hypothesis test shows that economic and socio-cultural factors significantly influence community support for tourism development. However, environmental factors do not significantly affect it.

The contribution of the research is the model of community support for the development of coastal and marine tourism with the measurement of economic, socio-cultural, and environmental impacts. To increase community support for tourism, it is necessary to increase the income, job opportunities, security, protection of traditional culture, and welfare of the community.

The research limitation is that the measurements of environmental factors are limited and only include positive impacts. For further research, the researcher can include positive and negative measurements of economic, socio-cultural, and environmental factors. It is advisable to use negative environmental impacts, such as damage to marine biota by tourists or ignorant residents towards marine biota. Due to the low $\mathrm{R}$-squared and effect size, it is necessary to look for other variables that influence community support, such as government policies at the regional and national levels. The relationship between economic, sociocultural, and environmental factors on community support may be repositioned. The influence of economic and environmental factors on community support through culture as a moderating variable is also recommended.

\section{REFERENCES}

Adhikrisna, Y. B., Hidayat, W., \& Arifin, Z. (2016). Analisis pengaruh pariwisata terhadap produk domestik regional bruto kabupaten/kota provinsi Jawa Timur 2011-2014. Jurnal Ekonomi Pembangunan, 14(1), 59-70. https://doi.org/10.22219/jep.v14i1.3847

Afifah, A. N., Sabila, F., \& Hardi, O. S. (2019). Analisis karakteristik habitat penyu sisik Taman Nasional Kepulauan Seribu, Pulau Pramuka, Kabupaten Kepulauan Seribu, Provinsi DKI Jakarta. Jurnal Siliwangi Seri Sains dan Teknologi, 5(1), 23-27.

Amalia, N., Kusumawati, A., \& Hakim, L. (2018). Partisipasi masyarakat dalam pengembangan desa wisata serta dampaknya terhadap perekonomian warga di Desa Tulungrejo Kota Batu. Jurnal Administrasi Bisnis, 61(3), 48-56.

Alonso, A. D., \& Nyanjom, J. (2016). Tourism, quality of life, and residents of a rural town. Tourism Analysis, 21(6), 617-629. https://doi.org/10.3727/10835421 6X14713487283165

Badan Pusat Statistik Kabupaten Kepulauan Seribu. (2018). Kecamatan Kepulauan Seribu Utara dalam angka 2018. Retrieved from https://kepulauanseribukab. b p s . g o.id/public a tion/2018/09/26/ e1363c48d4151dabf11cb609/kecamatan-kepulauanseribu-utara-dalam-angka-2018.html

Badan Pusat Statistik Kabupaten Kepulauan Seribu. (2019). Kecamatan Kepulauan Seribu Utara dalam angka 2019. Retrieved from https:// kepulauanseribukab.bps.go.id/publication/ $2019 / 09 / 26 / 0$ d0022895c34fd2680fc81b2/ kecamatan-kepulauan-seribu-utara-dalamangka-2019.html

Badan Pusat Statistik Kabupaten Kepulauan Seribu. (2020). Produk Domestik Regional Bruto Kabupaten Kepulauan Seribu menurut pengeluaran 2015-2019. Retrieved from https:// kepulauanseribukab.bps.go.id/ publication/ 2020/05/ 29/837bb80d076c5e8991fc097a/produk-domestikregional-bruto-kabupaten-kepulauan-seribumenurut-pengeluaran-2015-2019.html

Bakhsh, J., Potwarka, L. R., Nunkoo, R., \& Sunnassee, V. (2018). Residents' support for the olympic games: Single host-city versus multiple host-city bid arrangements. Journal of Hospitality Marketing \& Management, 27(5), 544-560. https://doi.org/10.108 0/19368623.2018.1398119

Boonsiritomachai, W., \& Phonthanukitithaworn, C. (2019). Residents' support for sports events tourism development in Beach City: The role of community's participation and tourism impacts. Sage Open, 9(2), 1-15. https://doi.org/10.1177/2158244019843417 
Cárdenas-García, P. J., \& Pulido-Fernández, J. I. (2019). Tourism as an economic development tool. Key factors. Current Issues in Tourism, 22(17), 20822108. https://doi.org/10.1080/13683500.2017.1420 042

Chang, H. M., \& Huang, Y. C. (2017). Residents' perceived marine tourism impacts and support development attitude-Case study of Jibei Island. Asian Journal of Environment \& Ecology, 5(2), 1-14. https://doi. org/10.9734/ajee/2017/38298

Chin, W. W. (2010). How to write up and report PLS analyses. In Handbook of Partial Least Squares: Concepts, methods and applications (pp. 655-690). Springer.

Diedrich, A., \& Aswani, S. (2016). Exploring the potential impacts of tourism development on social and ecological change in the Solomon Islands. Ambio, 45(7), 808-818. https://doi.org/10.1007/s13280-0160781-X

Eshliki, S. A., \& Kaboudi, M. (2017). Perception of community in tourism impacts and their participation in tourism planning: Ramsar, Iran. Journal of ASIAN Behavioural Studies, 2(4), 59-69. https://doi. org/10.21834/jabs.v2i4.207

García, F. A., Vázquez, A. B., \& Macías, R. C. (2015). Resident's attitudes towards the impacts of tourism. Tourism Management Perspectives, 13(January), 33-40. https://doi.org/10.1016/j.tmp.2014.11.002

Goni, J. I., \& Yustika, B. P. (2019). The presence of global value chain in coastal marine tourism. Jurnal Riset Manajemen dan Bisnis (JRMB) Fakultas Ekonomi UNIAT, 4(1), 137-152. https://doi.org/10.36226/ jrmb.v4i1.248

Gursoy, D., Ouyang, Z., Nunkoo, R., \& Wei, W. (2019). Residents' impact perceptions of and attitudes towards tourism development: A meta-analysis. Journal of Hospitality Marketing \& Management, 28(3), 306-333. https://doi.org/10.1080/19368623.2 018.1516589

Hair Jr, J. F., Hult, G. T. M., Ringle, C. M., \& Sarstedt, M. (2017). A primer on Partial Least Squares Structural Equation Modeling (PLS-SEM). Thousand Oaks: Sage.

Hsu, C. Y., Chen, M. Y., \& Yang, S. C. (2019). Residents' attitudes toward support for island sustainable tourism. Sustainability, 11(18), 1-16. https://doi. org/10.3390/su11185051

Hussain, K., Ali, F., Nair, P. K., Ragavan, N. A., \& Nair, V. (2019). Perceived impacts and residents' support for tourism development in Port Dickson, Malaysia. Turizam: Međunarodni Znanstveno-Stručni Časopis, 67(4), 351-364.

Kementerian Pariwisata dan Ekonomi Kreatif RI. (2019). Laporan Akuntabilitas Kinerja Kementerian Pariwisata tahun 2018. Retrieved from https://www. kemenparekraf.go.id/post/laporan-akuntabilitaskinerja-kemenparekrafbaparekraf

Lee, C. K. M, Zhang, S., \& Ng, K. K. H. (2019). In-plant logistics simulation model for the catering service industry towards sustainable development: A case study. Sustainability, 11(13), 1-11. https://doi. org/10.3390/su11133655

Li, X., \& Wan, Y. K. P. (2017). Residents' support for festivals: Integration of emotional solidarity. Journal of Sustainable Tourism, 25(4), 517-535. https://doi. org/10.1080/09669582.2016.1224889

Liao, L. C. C., Yang, T. M., \& Chang, H. M. (2015). A study of marine sport tourism development on island-A case study of Jibei in Penghu, Taiwan. Advances in Research, 4(2), 102-113. https://doi.org/10.9734/ air/2015/15031

Lim, J., Lo, M. C., Mohamad, A. A., Chin, C. H., \& Ramayah, T. (2017). The moderating impact of community support on tri-dimensional impacts of tourism (economic, socio-cultural, \& environmental) towards rural tourism competitive advantage. International Journal of Business \& Society, 18(S4), 869-880.

Martín, J. M. M., Martínez, J. M. G., \& Fernández, J. A. S. (2018). An analysis of the factors behind the citizen's attitude of rejection towards tourism in a context of overtourism and economic dependence on this activity. Sustainability, 10(8), 1-18. https:// doi.org/10.3390/su10082851

Naidoo, P., \& Sharpley, R. (2016). Local perceptions of the relative contributions of enclave tourism and agritourism to community well-being: The case of Mauritius. Journal of Destination Marketing \& Management, 5(1), 16-25. https://doi.org/10.1016/j. jdmm.2015.11.002

Nejati, M., Mohamed, B., \& Omar, S. I. (2014). Locals' perceptions towards the impacts of tourism and the importance of local engagement: A comparative study of two islands in Malaysia. Tourism: An International Interdisciplinary Journal, 62(2), 135146.

Nunkoo, R., \& So, K. K. F. (2016). Residents' support for tourism: Testing alternative structural models. Journal of Travel Research, 55(7), 847-861. https:// doi.org/10.1177/0047287515592972

Paranita, E. S., Levyda, L., \& Giyatmi, G. (2019). Peningkatan literasi keuangan pemilik homestay di Pulau Harapan Kepulauan Seribu. WASANA NYATA, 3(2), 157-167.

Pratiwi, B. D., \& Pinasti, V. I. S. (2017). Pariwisata dan budaya (Studi peran serta masyarakat lokal dalam pengelolaan pariwisata di Kampung Pitu, Nglanggeran, Patuk, Gunung Kidul). E-Societas, 6(8), 1-11.

Rasoolimanesh, S. M., Jaafar, M., Kock, N., \& Ahmad, A. G. (2017). The effects of community factors on residents' perceptions toward World Heritage Site inscription and sustainable tourism development. Journal of Sustainable Tourism, 25(2), 198-216. https://doi.org/10.1080/09669582.2016.1195836

Rosalina, A. D., Yonvitner, Y., \& Imran, Z. (2019). Perilaku pesnorkel terhadap ekosistem terumbu karang (Studi kasus di Taman Nasional Laut Kepulauan Seribu, DKI Jakarta). Jurnal Ilmu Pertanian Indonesia, 24(4), 327-336. https://doi.org/10.18343/ jipi.24.4.327 
Šegota, T., Mihalič, T., \& Kuščer, K. (2017). The impact of residents' informedness and involvement on their perceptions of tourism impacts: The case of Bled. Journal of Destination Marketing \& Management, 6(3), 196-206. https://doi.org/10.1016/j. jdmm.2016.03.007

Séraphin, H., Platania, M., Spencer, P., \& Modica, G. (2018). Events and tourism development within a local community: The case of Winchester (UK). Sustainability, 10(10), 1-23. https://doi.org/10.3390/ su10103728

Su, L., \& Swanson, S. R. (2020). The effect of personal benefits from, and support of, tourism development: The role of relational quality and quality-of-life. Journal of Sustainable Tourism, 28(3), 433-454. https://doi.org/10.1080/09669582.2019.1680681

Yu, C. P., Cole, S. T., \& Chancellor, C. (2018). Resident support for tourism development in rural midwestern (USA) communities: Perceived tourism impacts and community quality of life perspective. Sustainability, 10(3), 1-17. https://doi.org/10.3390/su10030802 